\title{
Interactive Design Concept on Art: 1 New Museum and Art Space
}

\author{
Stella Stella ${ }^{1}$ Eddy Supriyatna Marizar ${ }^{2 *}$ Maria Florencia $^{2}$ \\ ${ }^{1}$ Student of Interior Design, Universitas Tarumanagara, Jakarta, Indonesia \\ ${ }^{2}$ Lecturer of Interior Design, Universitas Tarumanagara, Jakarta, Indonesia \\ "Corresponding author.Email: eddysmarizar@yahoo.com
}

\begin{abstract}
Art: 1 New Museum and Art Space is an art gallery called the Mon Decor Art Gallery founded by Martha Gunawan in 1983. The Mon Decor Art Gallery's limited space made this gallery moved in 2011 and changed its name to Art: 1 New Museum and Art Space with the hope of becoming a place to showcase the work of artists and carry out various other activities. Nonetheless, the Indonesian people's interest in visiting museums decreases, so the museum needs to improve facilities and services to attract public interest and not compete with other tourist attractions. Consequently, the designer will redesign Interior Art 1: New Museum and Art Space with a more interactive concept for visitors. This study used a descriptive-qualitative method by conducting literature studies, participating-observation, and semi-structured interviews. The observed data will be analyzed and compared with the reference theory using the directed content analysis approach. The research results are an interactive museum concept to attract the broader public with more contemporary concepts, more advanced and sophisticated facilities.
\end{abstract}

Keywords: Art museum, interior, interactive, contemporary

\section{INTRODUCTION}

Initially, Art: 1 New Museum and Art Space was an art gallery called the Mon Decor Art Gallery founded by Martha Gunawan in 1983. Mon Decor Art Galleries are located in Plaza Senayan, Wisma Mulia, and Grand Indonesia Shopping Town. Nevertheless, the Mon Decor Art Gallery needed more space to exhibit works of art, so in 2011 Art: 1 New Museum and Art Space were established as a forum for exhibiting the works of artists and carrying out various other activities [1].

However, there is the fact that the interest of Indonesian people to visit museums is decreasing [2].Therefore, museums need to improve facilities or services in order to attract public interest and not compete with the attractiveness of other tourist attractions [3]. There are several things that can increase the attractiveness of the museum, namely: 1) Increase the visual elements in the interior of the museum so that it becomes an attraction; 2) The museum must keep up with the times (up-tp-date) by using a more modern appearance and using more advanced (high-tech) facilities so that the information conveyed in the museum can be well received and provide insight for visitors; 3 ) The museum must be interactive so that visitors can interact with what is in the museum [4].

Based on preliminary observations, the researcher concluded that Art: 1 New Museum and Art Space has not met these criteria and is not yet in demand. Accordingly, researchers will redesign Art 1: New Museum and Art Space. Art 1: New Museum and Art Space can attract broader public interest with the more up-to-date concept, more advanced facilities, and become an interactive museum. In this study, the area discussed is limited to the art pace area, Galam Zulkifli area, also digital and contemporary exhibition area.

\section{THEORETICAL REVIEW}

\subsection{Museum and Gallery}

The museum is a non-profit permanent business entity, serving the community and its development, with an open nature by collecting, conserving, researching, communicating, and exhibiting real objects to the public for the study's needs, education, and pleasure [5]. In contrast, the gallery can accommodate visual communication activities in a room between a collector or artist and the broader community through exhibition activities [6].

\subsection{Interactive Design}

The museum's primary function is to carry out research, conservation or preservation, and communication as an aspect of mediation with the community. The communication in question includes disseminating research results in the form of knowledge relating to how good communication is in an exhibition system in a museum so that errors do not occur when presenting an information material [7]. Thus, we need an interactive design concept to 
design a space that can communicate and interact with users of the space.

\subsection{Exhibition Area}

The exhibition area is a forum for activities carried out by users in the museum, which functions as the main element of visualization, space as a program, space as a layout arrangement in a museum [8]. The exhibition area also functions to display collectibles or merchandise. Exhibition activities have a function to arouse art appreciation in society and as a medium of communication between artists and audiences. Exhibition activities are a means of fostering a public appreciation of art. The form of appreciation consists of creative appreciation and affective appreciation [9].

\section{METHOD}

\subsection{Research Methodology}

This research uses a descriptive-qualitative method with the results of this study: descriptive data, pictures, and not numbers caused by the application of quantitative methods [10] [11]. Data collection methods used were literature study, participated-observation, and semi-structured interviews with staff and visitors at Art: 1 New Museum and Art Space. The observed data will be analyzed and compared with the reference theory using the directed content analysis approach [10]. This study's output is an interactive design concept that is following the image of Art: 1 New Museum and Art Space.

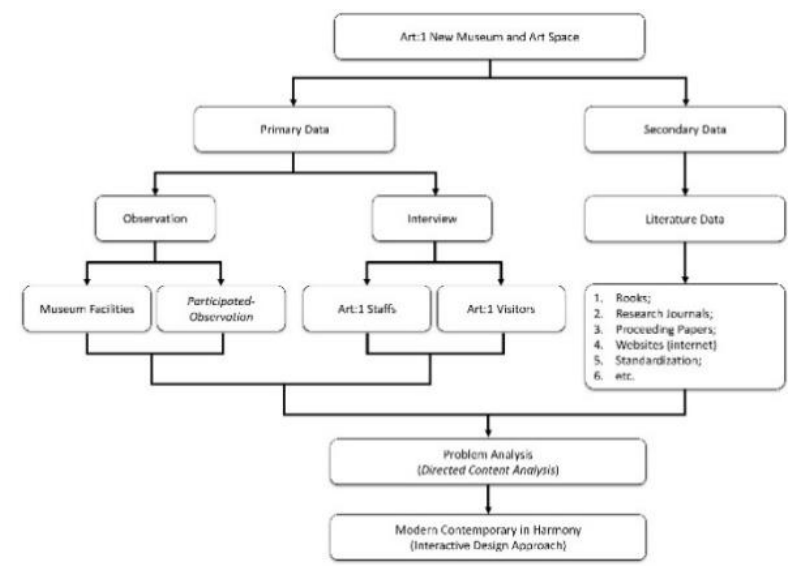

Figure 1 Methodological framework

Source: Authors, 2021

\subsection{Case Study}

Art: 1 The New Museum and Art Space are located at Rajawali Selatan No.3, Central Jakarta. They were initially known as the Mon Décor Gallery in 1983. Mon Decor has been a pioneer in the art gallery business in Jakarta for more than 30 years, with various well-known Mon Décor Gallery collections, including Old Masters Indonesia, Euro Indo, Modern Masters, and Contemporary Indonesian Collections. In 2011 Mon Decor Gallery reinvented its original art gallery concept and expanded into a private museum, art space, and art institute to support Indonesia's art infrastructure and to showcase the Mon Décor Gallery collection over the past thirty years. A relocation accompanied this shift to a larger and more complete exhibition space in Kemayoran called Art: 1. This 4,000 square meter building offers products and services dedicated to art, art development, and activities for Indonesian art students, art audiences, and the art market.

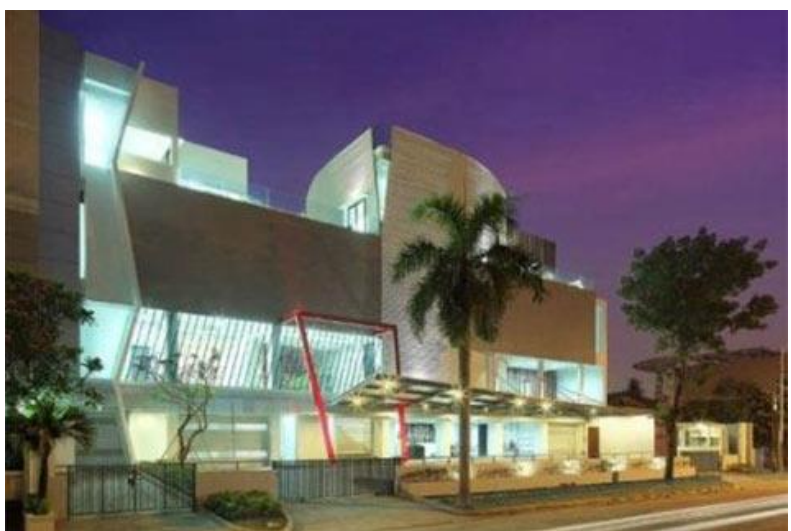

Figure 2 Art:1 New Museum and Art Space

Source: www.traveling.bisnis.com [13]

\section{FINDINGS AND DISCUSSIONS}

Art: 1 New Museum and Art Space, previously known as Mon Décor Gallery (1983), is a pioneer in the art gallery business in Jakarta. In 2011 Mon Décor Gallery was relocated to a more comprehensive exhibition space in Kemayoran called Art: 1. Nevertheless, based on the researchers' observations, it was concluded that Art: 1 is less attractive to the broader community. Consequently, the researcher will redesign Art:1 New Museum and Art Space with the concept of Modern Contemporary in Harmony with an interactive design approach.

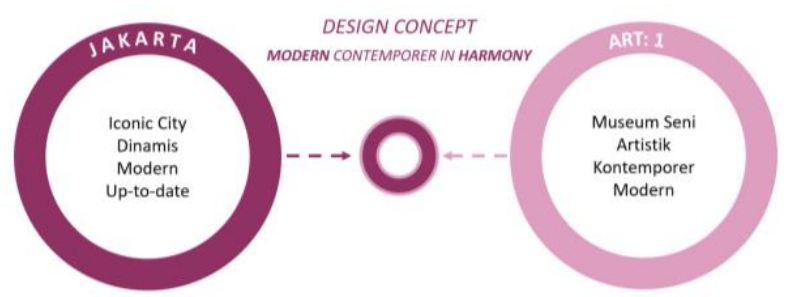

Figure 3 Design concept diagram Source: Authors, 2020

The researcher applies the Modern design concept because it adapts to the image of Art:1. Besides, this modern concept also aims to make the interior of Art: 1 simpler so that visitors can focus more on the artworks displayed in museums and art spaces without being distracted by interior 
ornaments that are more focal points than artwork. The contemporary style that is applied has connotated being upto-date, marked by design changes that always adjust to the time and era. Changes in shape will accompany design changes, appearance, type of material, and technology used. The concept of harmony in this design means that this design concept means a unit where all the elements are complementary and continuous to produce a balanced composition.

On the first floor of art space area, there is the main lobby which contains a reception counter, waiting area, book collections area, and an exhibition area for works by Agusto De Sa, Pure Evil, and Noel John Harnden. The design concept looks modern, dominated by white and gray with red accents on the waiting area chairs on this floor. The interactive design concept applied is the use of vending machines and book collections designed with self-service. By applying this concept, the interior space indirectly creates interaction with visitors.
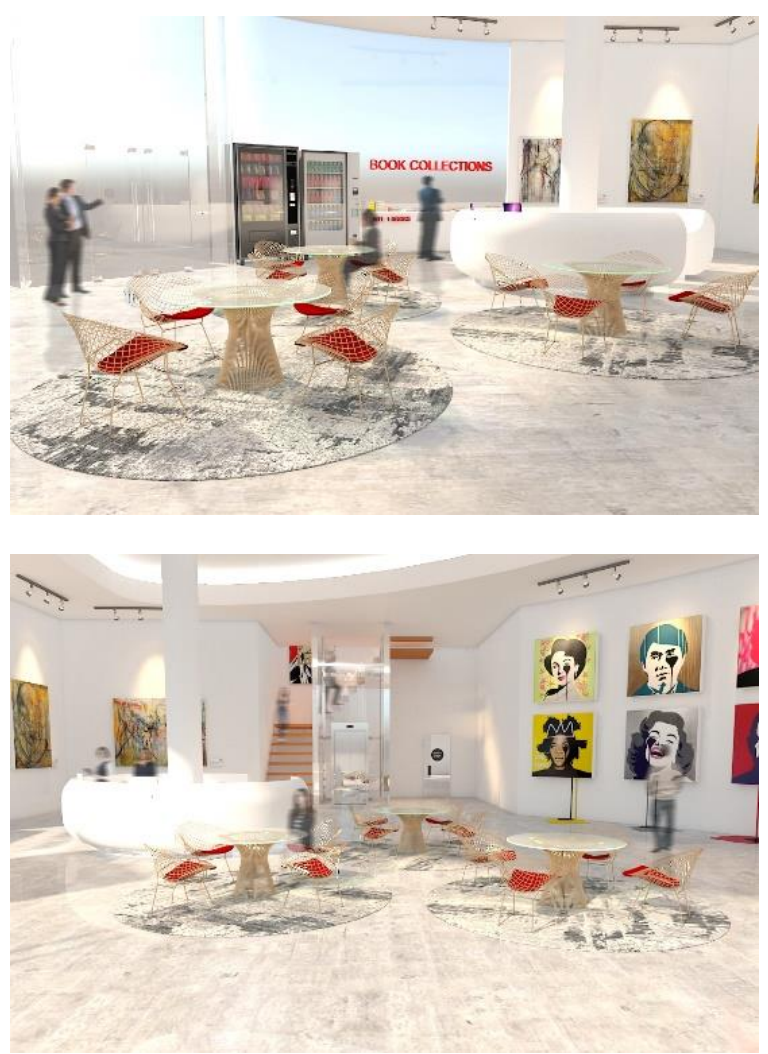

Figure 4 Vending machine and book collections area Source: Authors, 2020

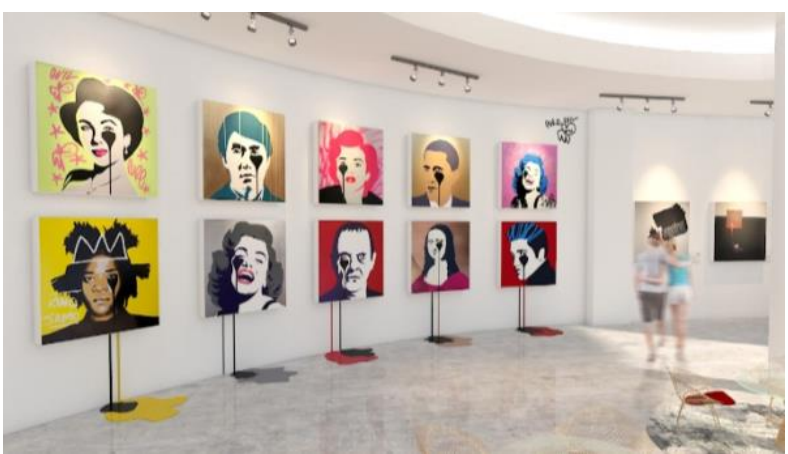

Figure 5 Pure evil's artworks area on the first floor Source: Authors, 2020

The second floor serves as a public exhibition area, an exhibition area for Balinese artists, and a digital and contemporary exhibition area. The concept in the secondfloor exhibition area is similar to the concept on the first floor. The dominant color on this floor is white to focus more on the existing artwork in the museum and not be distracted by the elements or colors of the museum's interior design. The floor uses exposed concrete, and the ceiling is semi-exposed with suspended ceilings.

In the middle of the room, there is a semi-transparent partition made of iron pipe material. This partition serves as a room divider to direct the circulation of visitors, but the room does not feel cramped because of the partition in the middle of the room. There are several interactive design concepts on this floor, specifically the use of interactive wall lights. The lights on the walls of the exhibition area will light up when a visitor passes. When the light is on, visitors will hear a voice that explains the work that the visitor is seeing. This concept can make the room's atmosphere more extraordinary with the interaction between the interior and visitors.
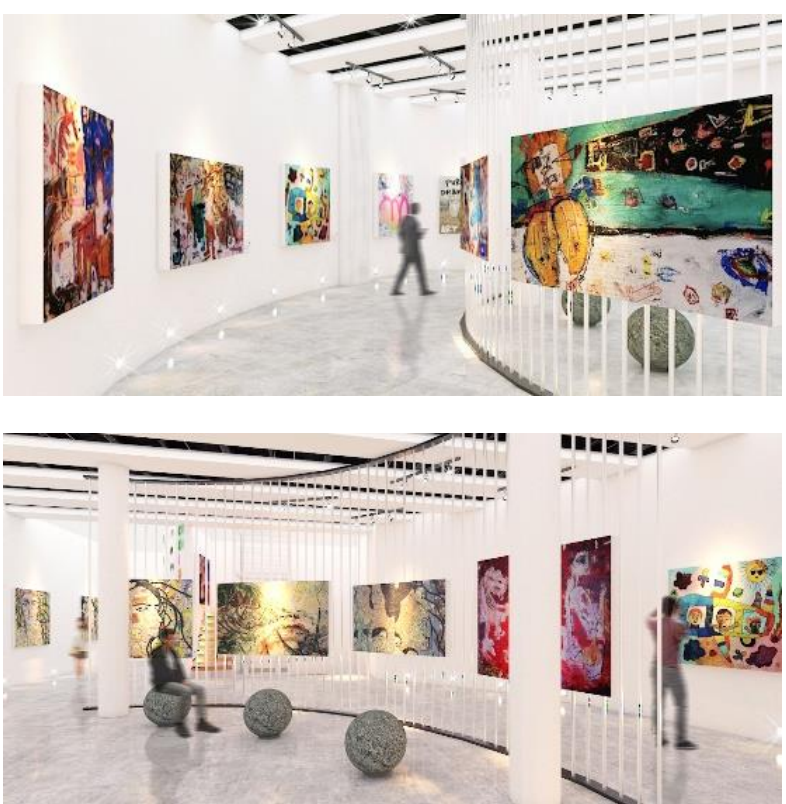

Figure 6 Interactive wall light on the second floor Source: Authors, 2021 
Aside from the public exhibition area, there are also digital and contemporary exhibition spaces on the second floor. This space exhibits contemporary paintings, an exhibition of digital artworks, and a space to exhibit the most recent installation work in Art: 1, namely Beetle Sphere. This room is designed in a circular shape to aim that the visitor's circulation is directed and follows the storyline. The researcher provides several concrete balls in the exhibition area, intending to be a place to sit for visitors who want to observe works for a longer time. In contrast, the digital exhibition area is an area to exhibit digital artwork. To exhibit digital works, researchers provide led monitors so that the artwork can change as needed. Researchers also designed the panels in this room equipped with indirect light. This indirect light's color and temperature can change according to the mood and impression produced from the artwork

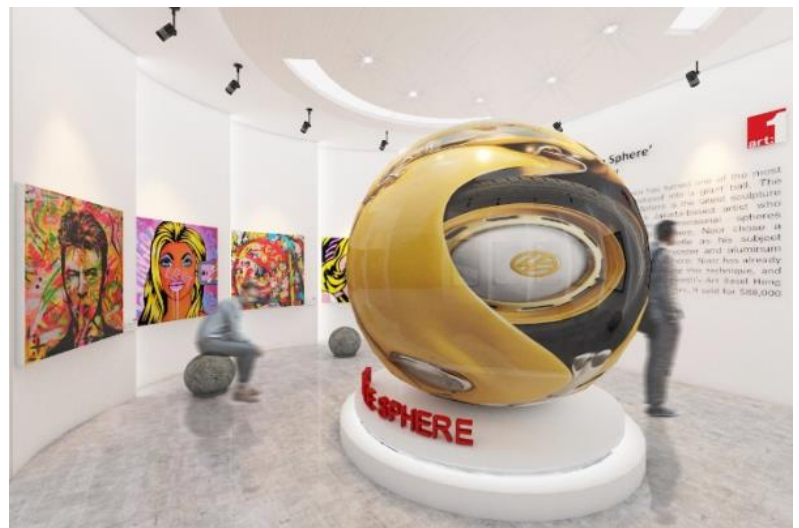

Figure 7 Contemporary exhibition area on the second floor

Source: Authors, 2020

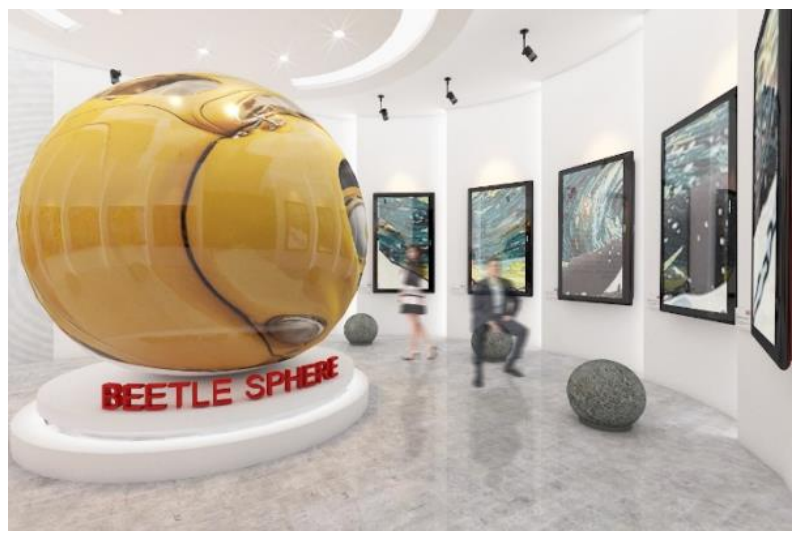

Figure 8 Digital exhibition area on second floor Source: Authors, 2020

The design concept on the third floor is the same as on the first and second floors. Where the white color and exposed concrete floor are dominant. The third floor's main attraction is Area Intip Karya (the peephole area). Visitors can peek at the artwork (painting) behind the walls, thereby creating an interaction between interior design and visitors. In area intip karya, he researcher chose Shingo Okazaki's artwork because it has a deep meaning about life. Consequently, the researcher considers Shingo Okazaki's work suitable to be placed in Area Intip Karya because it follows humans' psychological facts who like to "peek" about life. On the wall, the researchers designed wooden blocks arranged in an up and down pattern. The philosophy is related to Shingo Okazaki's works, where human life is always dynamic, sometimes up, sometimes down. Then, at each end of these blocks, an indirect lamp is given with the philosophy that there is always a "light" that will make humans rise again at every lowest point in human life.

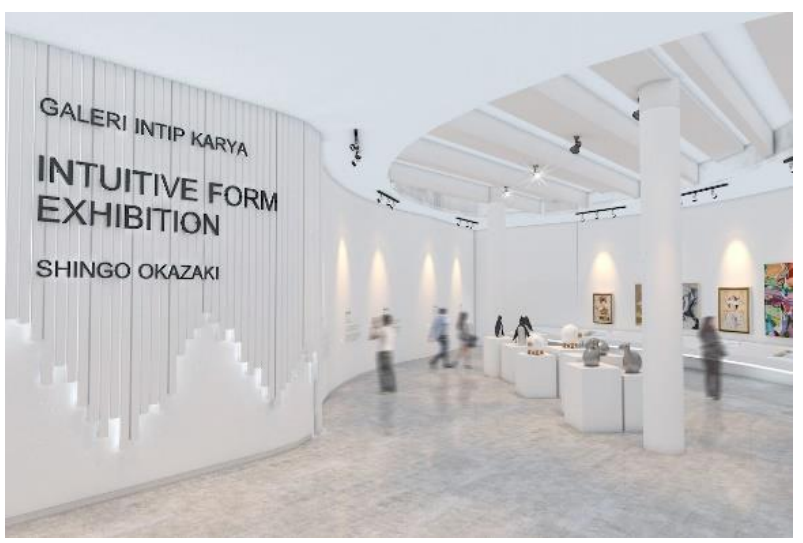

Figure 9 Area Intip Karya on the third floor

Source: Authors, 2020

Besides Area Intip Karya, there is also a public exhibition area where the exhibition area is equipped with an interactive TV. This interactive TV serves to provide information about the name of the artworks, the type of artworks, the history of the artworks, the artist, the price of the painting, and various information needed by visitors regarding the artwork on display. Therefore, visitors will get detailed information about the artwork on display as study material, knowledge, and consideration for buying artwork.

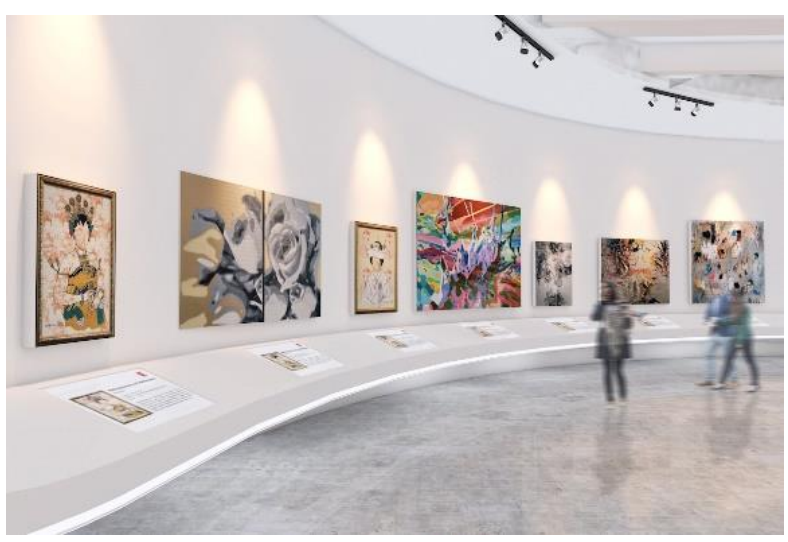

Figure 10 Interactive TV on the third floor

Source: Authors, 2020

This discussion's final area is the Galam Zulkifli area, which is an exhibition area for a $300 \times 900 \mathrm{~cm}$ masterpiece from Galam Zulkifli. This painting's image can change 
depending on the lighting technique given, such as general lighting, no lighting (darkened), or using ultraviolet light. Because it takes 5-10 minutes to enjoy the artwork, the researcher provides several bean bags as seats for visitors. Researchers also provide floor specifications using soft synthetic grass covered with white carpet. Hence, visitors can enjoy the work more comfortably, and the information conveyed by the work can be entirely accepted.
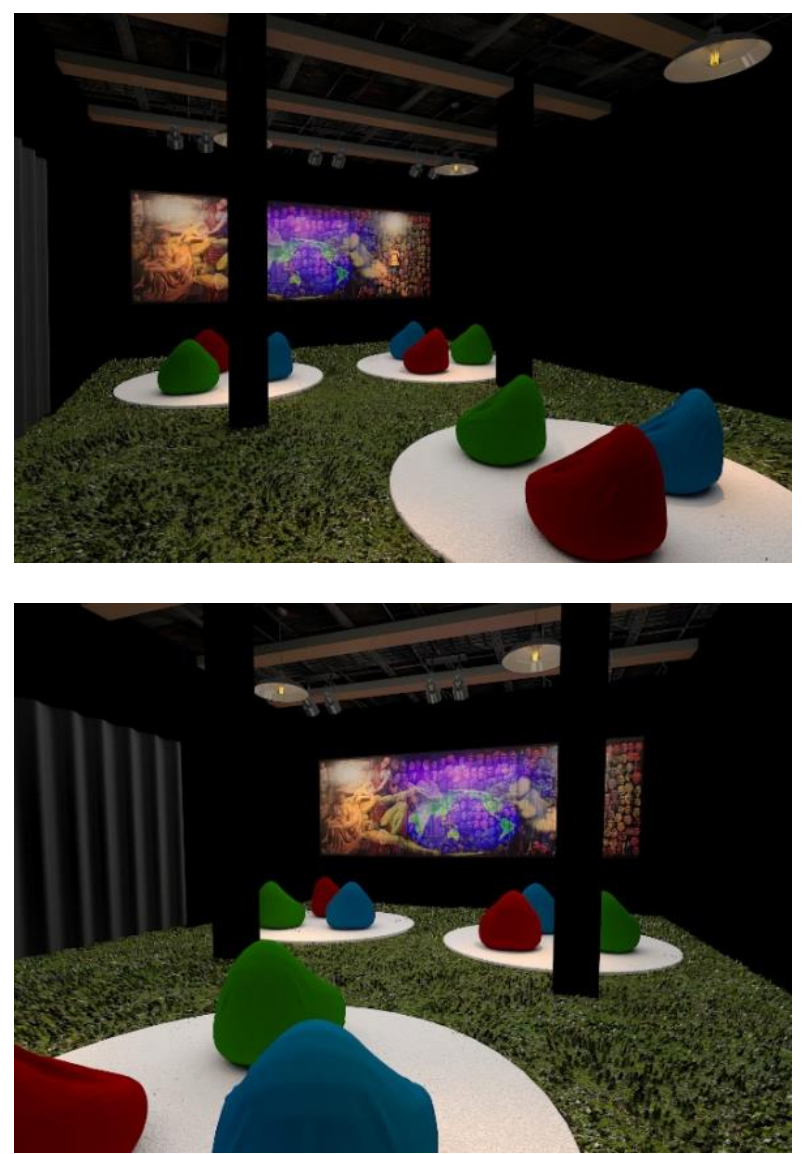

Figure 11 Galam Zulkifli area on the third floor Source: Authors, 2020

\section{CONCLUSIONS}

Based on the analysis, the researcher concluded that in the existing conditions, Art: 1 New Museum and Art Space was still less attractive to the broader community because the initial design concept was less up-to-date and interactive with visitors. Consequently, the researcher designed a modern contemporary in harmony concept. The modern concept choice aims to make the interior of Art: 1 look simple with geometric shapes and a monochromatic color scheme. The goal is that visitors can focus on the artwork without being distracted by complex interior elements.

The designer uses an interactive design approach to create interaction between interior rooms and visitors to give visitors a separate space and experience. The interactive design elements that are applied include the self-service concept on the vending machine and book collection - the interactive wall light concept on the second floor, the concept of the indirect lamp, which changes according to the mood of the painting in the digital and contemporary exhibition area, the peep work concept, the use of interactive TV on the third floor, and lastly is the use of bean bags to enjoy the artwork in the Galam Zulkifli area.

Therefore, the application of interactive design concepts in designing Art: 1 can increase visitor enthusiasm so that all information conveyed can be well received by visitors.

\section{ACKNOWLEDGMENT}

We gratefully thanks to Interior Design study program of Tarumanagara University for supporting this research.

\section{REFERENCES}

[1] Capital of Culture, "Contemporary art at Art:1 New Museum," 08 August 2018. [Online]. Available: https://nowjakarta.co.id/magazine-issue/capital-ofculture/contemporary-art-at-art-1-new-museum.

[2] S. Noviyanti, "Museum di Indonesia Masih Minim Peminat," 23 November 2014. [Online]. Available: https://travel.kompas.com/read/2014/11/23/1102002/ Museum.di.Indonesia.Masih.Minim.Peminat. [Accessed 18 February 2020].

[3] Lelo and M. A. Laksono, "Perancangan Desain Interior Museum Seni Rupa dan Keramik , Jakarta," Narada: Jurnal Desain \& Seni, vol. 5, no. 2, pp. 9-22, 2018.

[4] H. Dahruddin, "LIPI Rangsang Minat Masyarakat Ke Museum," 09 November 2016. [Online]. Available: http://lipi.go.id/lipimedia/lipi-rangsang-minatmasyarakat-ke-museum/16883. [Accessed 18 February 2020].

[5] International Council Of Museum, "ICOM Code of Ethics for Museums," International Council of Museums, Paris, 2013.

[6] Direktorat Museum, "Pengelolaan Koleksi Museum," Jakarta, Direktorat Museum, Direktorat Jendral Sejarah dan Purbakala, Departemen Kebudayaan dan Pariwisata, 2007.

[7] I. B. K. Subhiksu and G. B. R. Utama, Daya Yarik Wisata Museum: Sejarah dan Perkembangan di Ubud Bali, Yogyakarta: Penerbit Deepublish, 2018. 
[8] P. Salim, "Persepsi Kualitas Ruang Pamer Museum Seni: Sebuah Stufi Observasi," Narada: Jurnal Desain \& Seni, vol. 5, no. 2, pp. 23-32, 2018.

[9] T. Wartono, Pengantar Pendidikan Seni Rupa, Yogyakarta: Kanisius, 1984.

[10] L. J. Moleong, Metodologi Penelitian Kualitatif, Bandung: PT. Remaja Rosdakarya, 2007.

[11] J. W. Cresswell, Penelitian Kualitatif \& Desain Riset: Memilih Di Antara Lima Pendekatan, Yogyakarta: Pustaka Pelajar, 2015.

[12] A. Assarroudi, F. H. Nabavi, M. R. Armat, A. Ebadi and M. Vaismoradi, "Directed qualitative content analysis: the description and elaboration of its underpinning methods and data analysis process," Sage Journal, vol. 23, no. 1, pp. 42-55, 2018.

[13] T. N. Tsani, "Art: 1, Museum Modern Nan Menawan di Pusat Jakarta," 23 May 2014. [Online]. Available: https://traveling.bisnis.com/ read/20140523/ 224/230342/art-1-museum-modern-nan-menawan-dipusat-jakarta. [Accessed on $20^{\text {th }}$ January 2021] 